\title{
Secularism, Liberal Democracy and Islam in Europe: A Habermasian Critique of Talal Asad
}

\author{
Secularismo, democracia liberal e Islam en Europa: \\ una crítica habermasiana a Talal Asad
}

\author{
JONAS JAKOBSEN
}

Department of Philosophy, UiT The Arctic University of Norway, Norway

\begin{abstract}
This article develops a Habermasian critique of the work of the anthropologist Talal Asad. Drawing freely upon Habermas, I argue that Asad's critique of secularism and liberal democracy is flawed by «essentialism» (a reductionist binary between «Muslims» and «westerners») and «self-reference» (an implicit reliance on normative ideas that are explicitly rejected). Finally, I defend a Habermasian approach to the case of Islam in Europe against the Asadian approach.

KEYWORDS

ISLAM, JÜRGEN HABERMAS, LIBERAL DEMOCRACY, TALAL ASAD

\section{RESUMEN}

Este artículo elabora la crítica habermasiana del trabajo del antropólogo Talal Asad. Basándome flexiblemente en Habermas, defiendo que la crítica de Asad al secularismo y a la democracia liberal adolece de «esencialismo» (de un binarismo reduccionista entre los «musulmanes» y los «occidentales») y de «autorreferencia» (una dependencia implícita de las ideas noramtivas que se rechazan explícitamente). Finalmente, defiendo el enfoque habermasiano sobre el caso del Islam en Europa frente al enfoque asadiano.
\end{abstract}

PALABRAS CLAVE

ISLAM, DEMOCRACIA LIBERAL, JÜRGEN HABERMAS, TALAL ASAD

(C) Contrastes. Revista Internacional de Filosofia. Suplemento 20 (2015), pp. 113-125. ISSN: 1136-9922

Departamento de Filosofía, Universiad de Málaga, Facultad de Filosofía y Letras

Campus de Teatinos, E-29071 Málaga (España) 
The anthropologist Talal Asad is a strong proponent of the view that «western ideology», as expressed in the normative doctrines of secularism and liberal democracy, is fundamentally at odds with Islamic sensibilities and life forms. Such ideology, Asad holds, serves to justify not only western interventions and warfare in Muslim countries but also the more subtle marginalization and «disciplining»-in Foucault's sense- of Muslims in western societies: «the ideology of liberal democracy makes it difficult, if not impossible, to represent Muslims politically as Muslims». ${ }^{1}$

This chapter critically discusses Asad's work by drawing upon the work of Jürgen Habermas. First (in Section I), I present some of the most central claims raised in Asad's genealogical critique of secularism and liberal democracy. Secondly, (in Section II), I argue that Asad's approach is flawed by «essentialism» (a reductionist binary between «Muslims» and "westerners») and «selfreference» (an implicit reliance on normative ideas that are explicitly rejected). Finally (in Section III), I defend a Habermasian approach to the complex case of «Islam in Europe» against the Asadian approach.

\section{ASAD'S CRITIQUE OF SECULARISM AND LIBERAL DEMOCRACY}

Asad's work has not only had a profound influence on modern anthropology and postcolonial studies, it has also been discussed by philosophers, sociologists, and scholars of religious studies and used as a framework for ethnographic research or social critique. ${ }^{2}$ Asad is inspired by Michel Foucault, with whom he shares not only an explicit suspicion of universalism and «grand narratives», but also a genealogical and discourse analytical method of critique. Characteristic of this method is its claim to be purely descriptive: the genealogist simply investigates how we have come to think and act as we do, and does not attempt

1 Talal Asad, Formations of the Secular. Christianity, Islam, Modernity. (Stanford: Stanford University Press, 2003), 173.

2 See for example Saba Mahmood, Politics of Piety. The Islamic Revival and the Feminist Subject. (Princeton: Princeton University Press, 2005); C. Hirschkinde and D. Scott, eds., Powers of the Secular Modern: Talal Asad and His Interlocutors. (Stanford: Stanford University Press, 2006); Judith Butler, «The Sensibility of Critique: A Response to Asad and Mahmood», in Is Critique Secular? Blasphemy, Injury and Free Speech. (California: The Townsend Papers in the Humanities, 2009), 101-136; Andrew F. March, «Speaking about Muhammad, Speaking for Muslims», Critical Inquiry 37, 4 (2011): 806-821 and «Speech and the Sacred: Does the Liberal Defense of Free Speech Rest on a Mistake about Religion?», Political Theory 40, 3 (2012): 319-346. 
to prescribe how we should think and act. By displaying the historical contingency (the genealogy) of the assumptions and dispositions that form the implicit conceptual framework within which we live our lives, genealogical critique seeks to free us from the illusion that these are «universal» or «necessary»: «[Genealogy is] a way of working back from our present to the contingencies that have come to give us our certainties». ${ }^{3}$ Thus, turning the Kantian interest in the necessary conditions for contingent experience on its head, the genealogist investigates the contingency of our experiences of necessity.

Asad is especially concerned with tracing those epistemic and normative «certainties» that are constitutive of western modernity's definitions of religion and secularism. He uses the concept of «secularism» in variety of ways, the relation of which is not always clear. However, it seems to refer to at least three mechanisms of power: (1) secularism is an ideology which separates strictly between politics (the public sphere) and religion (the private sphere); (2) it centralizes all political power in a bureaucratic state with a monopoly on violence; (3) it «disciplines» citizens (in the Foucaultian sense of «governmentality») by making them internalize secular identities and "practices of the self». ${ }^{4}$

Contrary to the usual «western» view that a tolerant and peaceful society must adopt the political doctrine of secularism, Asad argues that secularism makes citizens easy targets of political manipulation by destroying their rootedness in life forms and traditions that could undermine their loyalty to state power. With reference to the «secular violence» of Nazism and Stalinism, as well as «secularists» such as Saddam Hussein, he states that «it is the secular modern state's awesome potential for cruelty and destruction [...] that deserves our sustained attention -as citizens and as anthropologists of modernity». ${ }^{5}$

According to Asad, liberal democracies, and not just secular dictatorships, are fundamentally based on violence and discipline. He therefore rejects as naïve the idea that a fair consensus on core political principles could be reached through democratic deliberation: in cases of real disagreement, the nation state (supported by a democratic majority) will not listen to minorities but will silence them with legal force «and the violence this implies». ${ }^{6}$ Furthermore, since the exclusion of certain groups and «certain types of claim» from public influence

3 Asad, Formations of the Secular, 16.

4 Asad, Formations of the Secular, 5.

5 Talal Asad, Genealogies of Religion: Discipline and Reasons of Power in Christianity and Islam. (Baltimore: The John Hopkins University Press, 1993). For a critique of Asadís conception of secular violence, see Sindre Bangstad, «Contesting Secularism/s. Secularism and Islam in the Work of Talal Asad», Anthropological Theory 9, 2 (2009): 188-208.

6 Asad, Formations of the Secular, 6 . 
also works in more subtle and disguised ways, the Habermasian idealization of the democratic public sphere is blind to the effects of power:

Ever since Habermas drew attention to the central importance of the public sphere for modern liberal society, critics have pointed out that it systematically excludes various kinds of people, or types of claim, from serious consideration. From the beginning the liberal public sphere excluded certain kinds: women, subjects without property, and members of religious minorities. ${ }^{7}$

One of the main goal of Asad's critique of secular methods of government is to delegitimize their claim to neutrality and universality: behind the notions of human rights, democracy, and secularism, hide thick layers of western cultural history, which Asad terms «the secular». For example, culturally specific attitudes towards pain, sexuality, and the body explain «the particular horror in Euro-America at the widespread custom of female genital mutilation in some African regions» and «the belief that female circumcision, unlike the male variety, interferes with the sexual pleasure of the woman» ${ }^{8}$ The secular belief that human beings «own» their own bodies like a private property also explain westerner's (but apparently not Muslim) aversions to child pornography - «even in cyberspace»-. ${ }^{9}$ However, individual self-ownership and self-responsibility are not restricted to the human body: the secularized subjects of modernity also insist on their right to think and believe whatever they want, independent of all authority and communal obligations. For Asad, this insistence is not only mistaken (since in fact we are always formed by powers and discourses beyond our control) it also turns a contingent and culturally biased doctrine into a universal standard for human maturity:

A subject possessing bodily integrity, able to freely express himself or herself, and entitled to choose for herself or himself what to believe and how to behave is not simply a «freestanding moral core of a political conception» to which people sign on. It is itself a thick account of what being human is -and one that underpins human rights. ${ }^{10}$

7 Asad, Formations of the Secular, 183.

8 Asad, Formations of the Secular, 148-149

9 Talal Asad, «Free Speech, Blasphemy, and Secular Criticism», in Is Critique Secular? Blasphemy, Injury and Free Speech (California: The Townsend Papers in the Humanities, 2009), 28.

10 Asad, Formations of the Secular, 150. 
According to Asad, the idea of a freely speaking, thinking, and acting individual is closely connected to a «protestant» definition of religion, according to which religious belief is essentially about the holding of epistemic truth claims, which can be freely adopted, scrutinized, or abandoned. However, Asad does not see this definition as a result of religious, cultural, or moral learning processes in their own right but as a «function» of the secular state: «[...] the modern idea of religious belief (protected as a right in the individual and regulated institutionally) is a critical function of the liberal democratic nation state». ${ }^{11}$ Secular political government, in other words, has created a certain kind of religious citizen by «protecting» the right to private belief while at the same time restricting religion as a public, practical and embodied concern. ${ }^{12}$

Since modern (western, protestantized) believers accept the secular state's definition of religion as the private holding of epistemic truth-claims, Asad argues, they are only religious «in the most vacuous sense». ${ }^{13}$ Thus, modern believers and nonbelievers may disagree on a cognitive level but they lead basically the same kind of life: «in modern capitalist society Christians and non-Christians, believers and non-believers, live more or less the same life». ${ }^{14}$ What matter in Islam, by contrast, are not abstract truth claims with no practical relevance but «practical rules and principles aimed at developing a distinctive set of virtues». ${ }^{15}$ Therefore, Islamic religiosity does not work very well under the conditions of liberal democracy: it is realized only as an embodied practice, it makes claims on social and political life, and it insists -contrary to our most «sacred» liberal beliefs- that «the individual does not own itself». ${ }^{16}$

11 Talal Asad, «Thinking about Belief, Religion and Politics», in The Cambridge Companion to Religious Studies. (Cambridge: Cambridge University Press, 2012), 56-57.

12 I agree with Jose Casanova that Asad overestimates the secular state's ability to form and control the religious life of its citizens and underestimates the genuinely religious-theological presuppositions for the rise of modern secularism. See Casanova, «Secularism Revisited: A Reply to Talal Asad», in Hirschkind \& Scott, eds., Powers of the Secular Modern: Talal Asad and His Interlocutors, 12-30.

13 Asad, Genealogies of Religion: Discipline and Reasons of Power in Christianity and Islam, 49.

14 Asad, «Thinking about Belief, Religion and Politics», 49. See also Talal Asad, «Modern Power and the Reconfiguration of Religious Traditions». Interview with Talal Asad by Saba Mahmood, Stanford Humanities Review 5, 11996. Available at http://www.stanford.edu/group/ SHR/5-1/text/asad.html. [Accessed 15 May 2014].

15 Asad, «Modern Power and the Reconfiguration of Religious Traditions», 9.

16 Asad, «Free Speech, Blasphemy, and Secular Criticism», 45. 
However, do all «Muslims» and «westerners» fit into Asad's grand postcolonial narrative? And, can Asad dismiss the normative vision of public deliberation without self-contradiction?

\section{II.ESSENTIALISM AND SELF-REFERENCE}

The first problem I wish to emphasize is the tendency in Asad to essentialize (or reify) group differences, in particular the assumed differences between «westerners» and «Muslims». Paradoxically, this way of thinking has certain similarities with the way in which anti-western Muslims and anti-Muslim westerners try to construct a deep conflict between two different civilizations. Of course, our present world is full of conflicts between interests, principles, or understandings that can be defined as «Western» or «Islamic», respectively, but my point is simply that Asad overlooks many important commonalities between Muslims and non-Muslims, on the one hand, and many internal differences and disagreements within the «Muslim» and the «western» world, on the other. ${ }^{17}$

For example, if western religion is such a «vacuous» and disembodied phenomenon as Asad holds, why would, say, abortion, gay marriage, or crucifixes in classrooms still fuel so many heated controversies? Is it the power of secularism that makes an atheist president of the United States unthinkable, or is it, as I would argue, a deep reluctance towards atheism and godlessness in large sections of American society, a antipathy shared by many Muslims worldwide? If Habermas is right that the «revivalist energies» of the American religious right were mobilized before and during the invasion of Iraq, then maybe «modern religion» is not so privatized and disempowered as Asad thinks. ${ }^{18}$

Asad's claim that «belief» is not central to Islam, whereas westerners can only understand religion as a set of theological beliefs, is problematic in several respects. Even Habermas, who admittedly has a rather «protestant» way of thinking about religion, writes that «genuine faith is not merely a doctrine, something believed, but also a source of energy that the person of faith taps into performatively to nurture her whole life». ${ }^{19}$ Asad also fails to capture the

17 The same tendency characterizes the work of Asad's former student, Saba Mahmmod, which I discuss in «Contextualising Religious Pain: Saba Mahmood, Axel Honneth and the Danish Cartoons», in Odin Lysaker \& Jonas Jakobsen, Recognition and Freedom: Axel Honneth's Political Thought. (Leiden: Brill 2014, forthcoming).

18 Jürgen Habermas, Between Naturalism and Religion. (Cambridge: Cambridge Polity Press, 2008), 116.

19 Habermas, Between Naturalism and Religion, 127. 
importance of religious truth claims and doctrines in Islam: even if Asad is right that Islam focuses more on bodily behavior, ritual and social belonging, it is no less interested in correcting and influencing the «inner beliefs» of its adherent than are other religions. Thus, the American political philosopher and scholar of Islamic law, Andrew March, writes that «if there is a historical religion that has minimized emphasis on theology and belief, Islam (across its various sects and traditions) is certainly not it». ${ }^{20}$

Please note that I am not saying that Islam has no distinguishing characteristics, or that Islamic and liberal democratic norms are always easy to reconcile. What I am saying is that Asad draws an overly stereotyped picture of what it can mean to be a «Muslim» or a «westerner». For example, it seems impossible under Asadian conditions that one could be a pious Muslim and a political secularist at the same time. How else can we understand Asad's central distinction between «Muslims» (who are marginalized by secularism) and «westernized Muslims» (who support secularism)? As the Norwegian anthropologist, Sindre Bangstad, rightly argues, the conception of a «westernized Muslim» is far from positive or even neutral within the framework of postcolonial thinking, and the idea of a «true» or «authentic» Muslim lurks in the background of such conceptions. ${ }^{21}$ But who has the authority to define what an authentic Muslim is? «To define is to repudiate some things and to endorse others», Asad writes, ${ }^{22}$ which makes it all the more strange that he omits to reflect upon why and how his own definitions endorse some things and repudiate others. In my view, one does greater justice to the manifold of different ways of being a Muslim by assuming -for example, with Habermas- that the normative ideas of political secularism and liberal democracy are not bound to a particular variant of «western culture» or «the secular», but are open to be interpreted and formed in different directions, also by Muslims.

A second problematic feature of Asad's approach is its tendency to rely implicitly on ideas and concepts, which he explicitly criticizes for their close alliance with «power». In his well-known critique of Foucault, Habermas uses the concept of «self-reference» to describe the aporias and self-contradictions that are produced when the genealogist tries to analyze all validity claims (all claims to truth and justice) as strategies of power while omitting to articulate and

20 March, «Speech and the Sacred: Does the Liberal Defense of Free Speech Rest on a Mistake about Religion?», 326.

21 Bangstad, «Contesting Secularism/s. Secularism and Islam in the Work of Talal Asad», 193.

22 Asad, «Thinking about Belief, Religion and Politics», 32. 
justify her own reliance on contestable claims to truth and normative rightness. ${ }^{23}$ In my view, this critique also applies to Asad's work. One example is Asad's critique of Habermas's normative idea of the democratic public sphere. As we saw in the previous section, Asad holds that minorities and marginalized groups are necessarily excluded from the public sphere: even though such groups have a liberal right to free speech, no one really listens. However, Habermas does not say that minorities and marginalized groups are in fact listened to, but that they should be: democratic inclusion is an on-going project, which requires majorities and the already included to take the perspective of outsiders, minorities, and immigrants ${ }^{24}$ and to always question established borders between the «public» and the «private» so that hidden or suppressed experiences of injustice can come to public attention. But Asad will have none of this, not even as a regulative, counterfactual ideal: «it isn't enough to respond to this criticism [Asad's criticism of Habermas], as is sometimes done, by saying that although the public sphere is less than perfect as an actual forum for rational debate, it is still an ideal worth striving for». ${ }^{25}$ For him, such a response misses the essential point that «the public sphere is a space necessarily (not just contingently) articulated by power». ${ }^{26}$ But what does that really mean? Does it mean that «power» cannot be more or less transparent, more or less legitimate? Asad rejects the idea that «sound argument can fatally undermine the ideological justifications of rulers», ${ }^{27}$ but what about his own arguments? Maybe they cannot «fatally» undermine repressive forms of secularism, but if they could not change anything for the better, why make them? In other words, if Asad wants to criticize the very ideal of public argumentation and argumentative critique of power, then he also criticizes -or «refers to»- himself.

\section{HABERMAS, DELIBERATIVE DEMOCRACY AND ISLAM IN EUROPE}

When Thilo Sarrazin, a member of the German Social Democratic Party, argued in 2010 that Muslims are the «wrong kind» of immigrants for Germany,

23 Jürgen Habermas, The Philosophical Discourse of Modernity. (Massachussets: The MIT Press, 1995), 105, 193.

24 See for example Jürgen Habermas: "Struggles for Recognition in the Democratic Constitutional State", in The Inclusion of the Other: Studies in Political Theory. (Massachussets: Polity Press, 2000), 203-238.

25 Asad, Formations of the Secular, 184.

26 Asad, Formations of the Secular, 184.

27 Asad, «Thinking about Belief, Religion and Politics», 50. 
Habermas stated in a critical reply that «we had, and apparently still have, to overcome the view that immigrants are supposed to assimilate the values of the majority culture and adopt its customs». ${ }^{28}$ However, Habermas still holds that a common political culture, in a «thin» sense, must be developed within the context of the democratic constitutional state. But what can bind very different citizens (who want to remain different) together in relations of solidarity and co-operation if not a «thick» cultural-religious tradition? Here, Habermas insists that a «post-conventional» political community must rely on the integrating force of communicative rationality itself, that is, on the active participation of its citizens in on-going processes of dialogue, mutual perspective taking, critique and learning. Only in this way can relations of mutual understanding, tolerance, trust, and solidarity be produced -however fragile and transitory- in spite of all our disagreements and differences in ways of thinking and living.

The political institutionalization of communicative rationality requires a constitution that secures a set of individual rights and liberties and a permanent democratic procedure at two levels: at the formal level of parliamentary representation and at the informal or «anarchic» level of public will-formation in the broadest sense. Habermas takes constitutionalism and democracy to be «co-original» in the sense that one is not possible without the other: the system of rights is only legitimate if discussed and interpreted by the citizens in democratic procedures, but these procedures, on the other hand, are only legitimate if all citizens effectively enjoy certain civil, political, social, economic and ecological rights. ${ }^{29}$ Deliberative democracy, therefore, insists that (formal) political government and will-formation is only legitimate to the extent that it is informed and influenced by the (informal) «communicative power» of deliberating citizens. Popular elections only temporarily pause deliberation so that decisions can be made and implemented.

Let us take the French Affaire du Foulard -the French debate about the Muslim hijab leading to a ban in public schools in 2004- as an example. In his comments on this case Habermas states that «the neutrality of the state», which he takes to be the core principle of political secularism, «can be violated just as much by the secular side as by the religious side. The Affaire du Foulard is an example of the former». ${ }^{30}$

28 Jürgen Habermas, «Leadership and Leitkultur», chronicle in The New York Times, October 28, 2010.

29 Jürgen Habermas, Between Facts and Norms. (Cambridge: The MIT Press, 1996), 82-131.

30 Habermas, Between Naturalism and Religion, 266. 
I agree with Habermas that one must have very good moral reasons to prevent cultural or religious groups from maintaining their traditions and expressing themselves in public; one must be able to show, for example, that these traditions violate basic human rights and principles of equal respect. Of course, veiling can be enforced on women against their will, but so can deveiling (as it was in pre-revolutionary Iran under the Shah and in different ways in today's France, Germany and Turkey). As long as so many autonomous Muslim girls and women desire and choose to wear the hijab for various reasons, sometimes even against their family's will and society's expectations, there is something illiberal about the secular state's interference with their clothing.

However, my point is not simply that the French laicite is not liberal enough, but rather that any political constitution has its biases, blind spots, and prejudices, and that this necessitates a permanent and inclusive democratic process of critical (re)interpretation: all citizens must be given a real opportunity to dispute the constitution in «open-ended democratic debates over the correct interpretation of constitutional principles in particular contexts». ${ }^{31}$ Consider the way in which public deliberations leading to the scarf ban where conducted in 2003-2004: no hijab-wearing women were interviewed, on the grounds that the Consultative Commission would «not be sensitive to their arguments». ${ }^{32}$

For Habermas, the constitutional state's dealing with civil disobedience, as exercised by some Muslims during the Affaire du Foulard, is a litmus test according to which the state's ability to resist the permanent danger of constitutional paternalism and cultural essentialism can be measured. Those who are suspected of being «enemies of the state», he writes, may very well turn out to be «radical defenders of democracy». ${ }^{33}$

As Veit Bader has rightly argued, Habermas is not always clear about the difference between «communication» and «consensus». Communicating with you is obviously not the same thing as agreeing with you. However, the conclusion drawn by Bader and other critics, namely that Habermas champions consensus and agreement at the expense of contestation and pluralism, or even

31 Habermas, Between Naturalism and Religion, 255.

32 Cecile Laborde, «Female Autonomy, Education and the Hijab», Critical Review of International Social and Political Philosophy 9, 3 (2008): 373; see also Dominique McGoldrick, Human Rights and Religion: The Islamic Headscarf Debate in Europe. (Portland: Hart Publishing, 2006), 84 and Seyla Benhabib, The Claims of Culture, Equality and Diversity in the Global Era. (Princeton: Princeton University Press, 2002), 94-100.

33 Habermas, Between Naturalism and Religion, 255. 
that he «fails to appreciate the depths of national diversity», ${ }^{34}$ is mistaken for the simple reason that it fails to understand his theory as a critical theory. In my view, the most promising critical principle in Habermas is not «consensus», but what Øjvind Larsen terms «the right to dissent»: the right to challenge any given consensus with new arguments. ${ }^{35}$ The right to dissent is not simply a right to speak but also a right to be listened to in fair processes of contestation, argument, and counterargument.

Habermas's critique of the French laicite should be read as a part of his general critique of so-called «rigid secularism» or «enlightenment fundamentalism» as developed in his analysis of the current «cultural war» over Islam in Europe ${ }^{36}$ However, Habermas is no less critical of the opposed «combatant» in this war: «radical multiculturalism». Radical multiculturalism sees cultures as «semantically closed wholes» and insists that:

With the exception of unsteady compromises, submission or conversion are the only alternatives for terminating conflicts between [...] cultures. Given this premise, radical multiculturalists cannot discern in any universalist validity claim, such as the claim for the universality of democracy and human rights, anything but the imperialist power claim of a dominant culture. ${ }^{37}$

In my view, Asad shares central assumptions with radical multiculturalism as understood by Habermas. It does seem that, on Asad's account, European Muslims have to choose between unsteady compromises, conversion to western culture, or complete submissiveness. Habermas, by contrast, insists that «consensus» can replace «compromise» and that «the fusion of horizons» can replace the choice between «submission or conversion». We do not have to agree with Habermas that «reaching understanding is the inherent telos of human speech ${ }^{38}$ to argue that communication oriented towards mutual understanding is a possibility in many cases. As we know from everyday life, we often seek

34 Biku Parekh, Rethinking Multiculturalism: Cultural Diversity and Political Theory. (Harvard: Harvard University Press, 2000), 312.

35 Øjvind Larsen, The Right To Dissent. The Critical Principle in Discourse Ethics and Deliberative Democracy. (Copenhagen: Museum Tusculanum Press, 2010).

36 Jürgen Habermas, «Notes on a Post-secular Society», Signandsight.com, 2008, 6. Available at: http://www.signandsight.com/features/1714.html. [Accessed 1 March 2011].

37 Habermas, «Notes on a Post-secular Society», 7.

38 Jürgen Habermas, The Theory of Communicative Action I+II. (Boston: Beacon Press, 1984), 287. 
not only to achieve certain strategic goals but also to reach an understanding with others regarding the legitimacy of our actions and utterances. Why should this be principally impossible in complex intercultural conflicts?

Needless to say, most cases of intercultural and religious dialogue will not result in consensus but, hopefully, in some form of «reasonable disagreement». ${ }^{39}$ However, as Seyla Benhaib argues, the very activity of public deliberation can have a civilizing effect even when no consensus is achieved: «the process of giving good reasons in the public sphere will articulate a civic point of view and a civic perspective of 'enlarged mentality'». ${ }^{40}$ This is also Habermas's point in arguing that «[through public deliberation] different communities can develop a more inclusive perspective by transcending their own universe of discourse». ${ }^{41}$ Asad, by contrast, is very skeptical of the idea that Muslims -and not just secular westerners- must also be prepared to expand their horizons and revise some of their views in communicative exchange with others. For example, he strongly dislikes Homi Baba's suggestion that Muslim immigrants in Europe need to engage in relations of «cultural translation $\rangle^{42}$ and to $\left\langle\right.$ reinvent» ${ }^{43}$ their own traditions in new social and political contexts. European assimilation of Muslims, Asad holds, works exactly by destabilizing identities and cultural essences: «the deessentialization of Islam is paradigmatic for all thinking about the assimilation of non-European peoples to European civilization». ${ }^{44}$ But why not say that some things (beliefs, scriptures, discursive traditions, etc.,) are essential to any version of Islam, while others are (and have always been) negotiated and debated -even with non-Muslims?- Why not admit that the very distinction between «essential» and «discussable» features of Islam is contested -also among Muslims?

According to Asad, Europe can only free itself from its deep and constitutive xenophobia if it gets rid of any kind of majorities so that «everyone may live as a minority among minorities». ${ }^{45}$ This suggestion, however, overlooks the fact that minority groups also consist of majority-minority relations and that these relations by no means are free of dominance and asymmetries of power. Although a Habermasian approach will go far in recognizing group difference

39 Habermas, Between Naturalism and Religion, 5.

40 Benhabib, The Claims of Culture, 115.

41 Jürgen Habermas and Charles Taylor, «Jürgen Habermas and Charles Taylor in Conversation», in Eduardo Mendieta and Jonathan Vanantwerpen, eds., The Power of Religion in the Public Sphere. (New York: Colombia University Press, 2011), 66.

42 Asad, Formations of the Secular, 180.

43 Asad, Genealogies of Religion, 263.

44 Asad, Formations of the Secular, 169.

45 Asad, Formations of the Secular, 180.

Contrastes. Revista de Filosofia. Suplemento 20 (2015) 
and recommends group based cultural and religious rights in some cases, it insists all the more uncompromisingly on the right of the human individual to question, discuss, or revise its own cultural-religious tradition, even to leave it completely, e.g., through apostasy or religious conversion. The right to dissent - - the freedom to say yes or no»- should be available to all minorities, and the last minority is always the individual.

Obviously, the individual right to dissent will sometimes conflict with the normative thrust of Asad's multiculturalism, which focuses on the possibility of preserving (non-western) cultural traditions: «the focus should be on what it takes to live particular ways of life continuously, co-operatively, and unselfconsciously»» ${ }^{46}$ By seeing minorities' cultural ways of life as the primary focus of justice, Asad ignores the many ways in which defenders of cultural homogeneity and «continuity» exercise ideological power by distorting or suppressing the free flow of communicative rationality, e.g. by immunizing particular beliefs or patterns of power against internal discussion or criticism. Religiously justified dominance and violence are very real phenomena, even within today's Europe, and also within some Muslim communities:

[I]n schools where some Muslim girls wear the headscarf-hijab and others do not, there is a strong pressure on the latter to conform. [...] [Muslim men's] pressure on young girls to conform can range from insults to community ostracism to violence. Fundamentalist Islamic groups have thus used schools to test and challenge the values of the French republic. ${ }^{47}$

The deliberative democratic hope, which is also my hope, is that illegitimate dominance over minorities as well as within minorities will come to critical public attention in a well-functioning liberal democracy. ${ }^{48}$

46 Asad, Formations of the Secular, 178.

47 Dominique McGoldrick, Human Rights and Religion: The Islamic Headscarf Debate in Europe, 64.

48 The double threat of state paternalism and «private» religious-cultural paternalism is analyzed by Laborde, «Female Autonomy, Education and the Hijab». 
